\title{
Phylogeography and population structure of Prochilodus lineatus Valenciennes, 1837 (Pisces: Prochilodontidae) population from the Paraguay River Basin
}

\author{
Rafael Splendore de Borba ${ }^{1}$, Josi Margarete Ponzetto ${ }^{2}$, Ricardo Luis Dalia ${ }^{1}$, Edson Lourenço da \\ Silva $^{3}$, Anderson Luis Alves ${ }^{4}$, Patrícia Pasquali Parise-Maltempi ${ }^{1 *}$ \\ ${ }^{I}$ Laboratório de Citogenética, Departamento de Biologia, Instituto de Biociências, Universidade Estadual \\ Paulista "Julio de Mesquita Filho" (UNESP), Av. 24A, 1515, CEP 13506-900, Rio Claro, SP, Brazil. \\ (http://ib.rc.unesp.br/) \\ ${ }^{2}$ Universidade Federal de São Carlos, São Carlo, SP, Brazil. (http://www2.ufscar.br/home/index.php) \\ ${ }^{3}$ Instituto Federal de Educação Ciência e Tecnologia do Piaui, Picos, PI, Brazil. (http://www5.ifpi.edu.br/) \\ ${ }^{4}$ Embrapa Pesca e Aqüicultura, Quadra 103 Sul, Av. Juscelino Kubitscheck, Conjunto 1, Lote 17, CEP 77015 - \\ 012, Palmas, TO, Brazil. (https://www.embrapa.br/pesca-e-aquicultura)
}

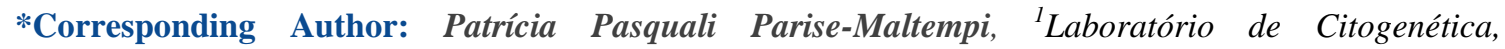
Departamento de Biologia, Instituto de Biociências, Universidade Estadual Paulista "Julio de Mesquita Filho” (UNESP), Av. 24A, 1515, CEP 13506-900, Rio Claro, SP, Brazil.

\begin{abstract}
Prochilodus lineatus is a species with high economic value that easily adapts to captive breeding. Hence it became a great interest for the development of fish breeding programs. Regular monitoring of genetic variation in natural fish stocks, especially in species of interest in conservation programs, is necessary to avoid a decline of genetic variability, which is of utmost importance for species conservation. In this sense, the objective of this study was to estimate the different genetic structures of P. lineatus and features of phylogeographic structures using mtDNA sequences of ATP synthase subunits 6 and 8 gene. The Neighbor-Joining analysis presented all kinds of population grouped in one clade. We detected low genetic distance values among the population (0, 5\%), and 27, 4\% for comparisons with the outer group. The low genetic distance and low AMOVA FST values suggest that, the population of the Mato Grosso Pantanal is panmictic.
\end{abstract}

Keywords: mtDNA, sequences, migratory fish, panmictic population.

\section{INTRODUCTION}

The Prochilodontidae family is an important group for commercial and subsistence fishing in the Neotropical region of South America [1]. It is composed of three genera and 21 species with the geographic distribution restricted to South America [2]. These fish perform great migrations during their reproductive cycle, resulting in a wide distribution in watersheds and homogeneity of morphological characters [2,3]. Prochilodus is the most important genus of the family, comprising of 13 of the 21 species described in the family, and Prochilodus lineatus is highly exploited for economic and scientific purposes.

$P$. lineatus has high economic value due to its easy adaptation to captive breeding [4] and its great nutritional value, including high protein content and essential amino acids [5]. Several studies related to induced reproduction, management, cultivation techniques, nutrition, growth, and other properties were conducted [6, 7]. However, natural population of $P$. lineatus have shown a decline in the last few years, owing primarily to overfishing, construction of hydroelectric plants and poorly planned ecotourism $[8,9]$. Studies related to the population and genetic structure of $P$. lineatus fish stocks is urgently needed. Therefore, we investigated the phylogeographic patterns and genetic variability among fish stocks of these species by analyzing the sequences of mitochondrial DNA. These results further our understanding some migrations patterns of these species.

\section{MATERials ANd Methods}

Twenty-Nine Prochilodus lineatus specimens from seven locations along the basins of the Paraguay and Parana Rivers (Table 1 appendices) were examined. Sixteen specimens, including thirteen $P$. 
Phylogeography and population structure of Prochilodus lineatus Valenciennes, 1837 (Pisces: Prochilodontidae) population from the Paraguay River Basin

lineatus and three Prochilodus nigricans (Spix \& Agassiz 1829) (Amazon basin), from Genbank were also examined. Salminus brasiliensis (Cuvier, 1816) (1) and Semaprochilodus sp. (1) (Genbank) were used as out-group taxa. Specimens were deposited in the collections of the Laboratorio de Citogenética of Universidade Estadual Paulista (Rio Claro, Brazil).

Table1: Identification numbers and location of the collected individuals of the species Prochilodus lineatus along with Prochilodus nigricans (*) and accession number of NCBI (\#).

\begin{tabular}{|c|c|c|}
\hline Identification & River/City/Country & Basin \\
\hline DPY 02 & Paraguay/Barra do Bugres/Brazil & Rio Paraguay \\
\hline DPY 03 & Paraguay/Barra do Bugres/Brazil & Rio Paraguay \\
\hline DPY 04 & Paraguay/Barra do Bugres/Brazil & Rio Paraguay \\
\hline DPY 05 & Paraguay/Barra do Bugres/Brazil & Rio Paraguay \\
\hline DCC 04 & Paraguay/Cáceres/Brazil & Rio Paraguay \\
\hline DCC 05 & Paraguay/Cáceres/Brazil & Rio Paraguay \\
\hline DGZ 01 & Cuiabazinho/Cuiabá/Brazil & Rio Paraguay \\
\hline DGZ 02 & Cuiabazinho/Cuiabá/Brazil & Rio Paraguay \\
\hline DGZ 03 & Cuiabazinho/Cuiabá/Brazil & Rio Paraguay \\
\hline DAS 01 & Cuiabá/Santo Antonio do Leverger/Brazil & Rio Paraguay \\
\hline DAS 02 & Cuiabá/Santo Antonio do Leverger/Brazil & Rio Paraguay \\
\hline DAS 03 & Cuiabá/Santo Antonio do Leverger/Brazil & Rio Paraguay \\
\hline DAS 04 & Cuiabá/Santo Antonio do Leverger/Brazil & Rio Paraguay \\
\hline DAS 05 & Cuiabá/Santo Antonio do Leverger/Brazil & Rio Paraguay \\
\hline DCBA 01 & Cuiabá/São Gonçalo/Brazil & Rio Paraguay \\
\hline DCBA 02 & Cuiabá/São Gonçalo/Brazil & Rio Paraguay \\
\hline DCBA 03 & Cuiabá/São Gonçalo/Brazil & Rio Paraguay \\
\hline DCBA 04 & Cuiabá/São Gonçalo/Brazil & Rio Paraguay \\
\hline DCBA 05 & Cuiabá/São Gonçalo/Brazil & Rio Paraguay \\
\hline DCBA SG 01 & Cuiabá/São Gonçalo/Brazil & Rio Paraguay \\
\hline DCBA SG 02 & Cuiabá/São Gonçalo/Brazil & Rio Paraguay \\
\hline DCBA SG 03 & Cuiabá/São Gonçalo/Brazil & Rio Paraguay \\
\hline DCBA SG 04 & Cuiabá/São Gonçalo/Brazil & Rio Paraguay \\
\hline DCBA SG 05 & Cuiabá/São Gonçalo/Brazil & Rio Paraguay \\
\hline AF2818323\# & Rio Paraguay/Corumbá/Brazil & Rio Paraguay \\
\hline AF281836\# & Rio Paraguay/Corumbá/Brazil & Rio Paraguay \\
\hline AF281829\# & Rio Paraguay/Riacho Mercedes/Argentina & Rio Paraguay \\
\hline AF281838\# & Rio Paraguay/Riacho Mercedes/Argentina & Rio Paraguay \\
\hline AF281833 & Rio Paraguay/Assunción/Paraguay & Rio Paraguay \\
\hline DCON 01 & Mojiguaçu/Pirassunga/Brazil & Parana \\
\hline DCON 02 & Mojiguaçu/Pirassunga/Brazil & Parana \\
\hline DCON 03 & Mojiguaçu/Pirassunga/Brazil & Parana \\
\hline DCON 04 & Mojiguaçu/Pirassunga/Brazil & Parana \\
\hline DCON 05 & Mojiguaçu/Pirassunga/Brazil & Parana \\
\hline AF281828\# & Rio Parana/ Bela Vista/ Argentina & Parana \\
\hline AF281830\# & Rio Parana/Bela Vista/Argentina & Parana \\
\hline AF281831\# & Rio Parana/ Bela Vista/Argentina & Parana \\
\hline AF281835\# & Rio Parana/ Bela Vista/Argentina & Parana \\
\hline AF281827\# & Rio da Prata/Buenos Aires/Argentina & Prata \\
\hline AF281834\# & Rio Bermejo/ Embarcacíon/ Argentina & Bermejo \\
\hline AF281837\# & Rio Uruguai/Gualeguaychu/Argentina & Uruguay \\
\hline AF281840*\# & Rio Amazonas/Manaus/Brazil & Amazon \\
\hline AF281841*\# & Rio Madeira/Manu/Peru & Amazon \\
\hline AF281842*\# & Rio Madeira/Manu/Peru & Amazon \\
\hline Sbrasilienses & Out-group & - \\
\hline 13661643 Semaprchilodus & Out-group & - \\
\hline
\end{tabular}

DNA was extracted with the technique described by [10]. The ATPase $6 / 8$ gene was amplified using PCR Mix (Qiagen, Hilden, Germany). PCR was performed in a thermo cycler (Eppendorf Master Cycler), the following set of primers was used: L8331 (5'-AA GCR TYR GCC TTT TAA GC-3') and H9236 (5'-GTT AGT GGT CAK GGG CTT GGR TC-3') [11]. The amplified DNA was purified with the EXOSAP enzyme and subsequently sequenced (MacroGen, Seoul, Korea).

Multiple sequence alignments to check indels or stop codons in sequences were analysed in BIOEDIT SEQUENCE ALIGNMENT EDITOR V7.0.5.3 [12]. Genetic distances among and within species were calculated using the Kimura 2-parameter (K2P) substitution model [13] and the divergence 
Phylogeography and population structure of Prochilodus lineatus Valenciennes, 1837 (Pisces: Prochilodontidae) population from the Paraguay River Basin

patterns suggested by those distances were graphically represented using a Neighbor-Joining (NJ) 1000 replicates bootstrap tree using MEGA v6.0 [14], this program was used too for the average base composition of sequences. Sequence alignments were carried out using the Clustal W algorithm [15].

A haplotype network (nested clades) was used to evaluate the association between haplotypes and their geographical distributions and was generated using the Network v. 4.6.1.2 program (Fluxus Technology). The population structure analyses were performed with the program ARLEQUIN ver. 2.0 [16]. Analysis of molecular variance (AMOVA) was used to assess the population structure and the geographical pattern of population subdivision

\section{RESULTS}

The tree topology generated by NJ method presented a large group, composed of all the analyzed samples (Figure 1).

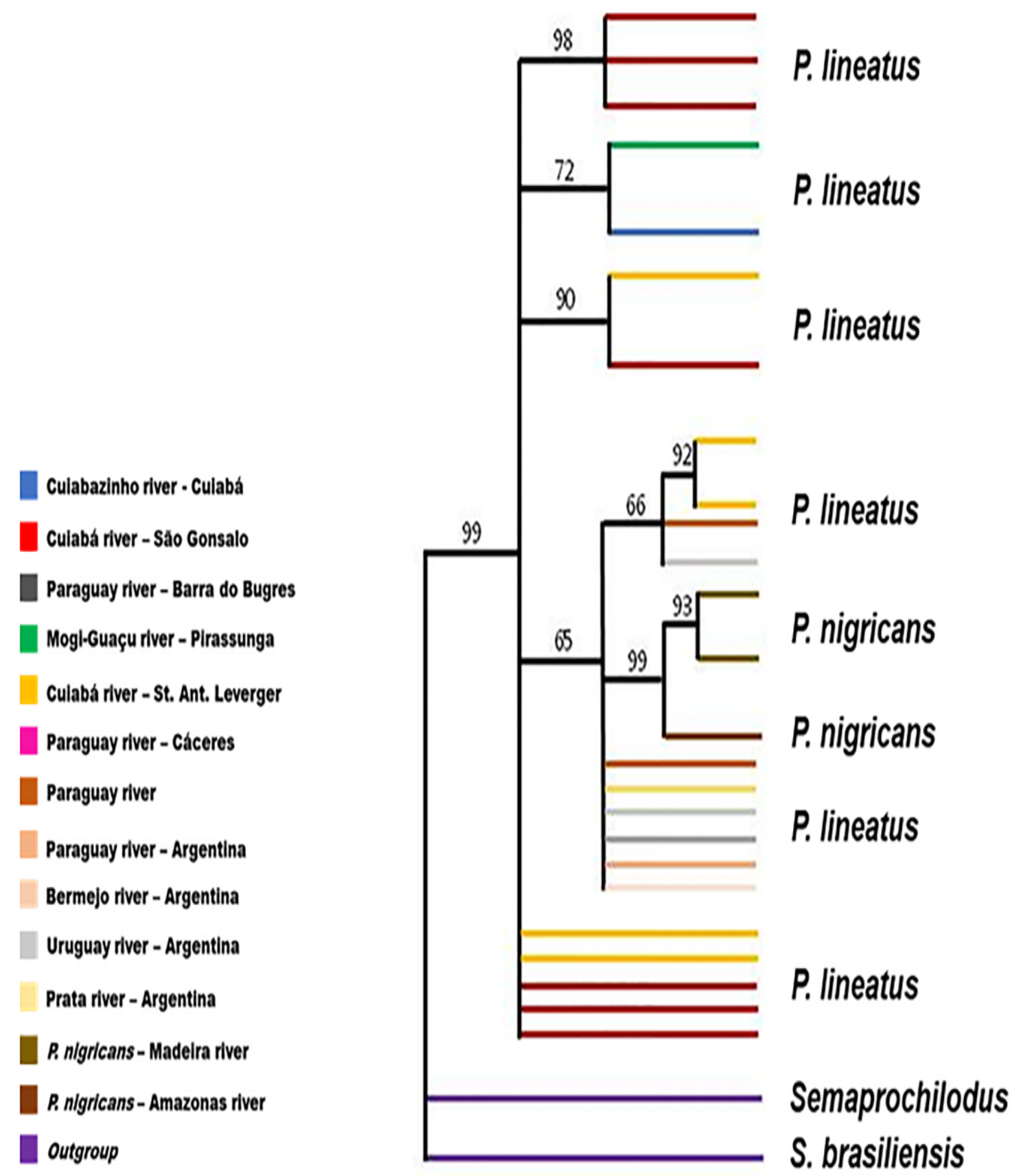

Figue1: a) Phylogenetic tree based on the ATPase 6/8 mitochondrial gene using NJ methods. Values on branches, present bootstrap values for BI. 
Phylogeography and population structure of Prochilodus lineatus Valenciennes, 1837 (Pisces: Prochilodontidae) population from the Paraguay River Basin

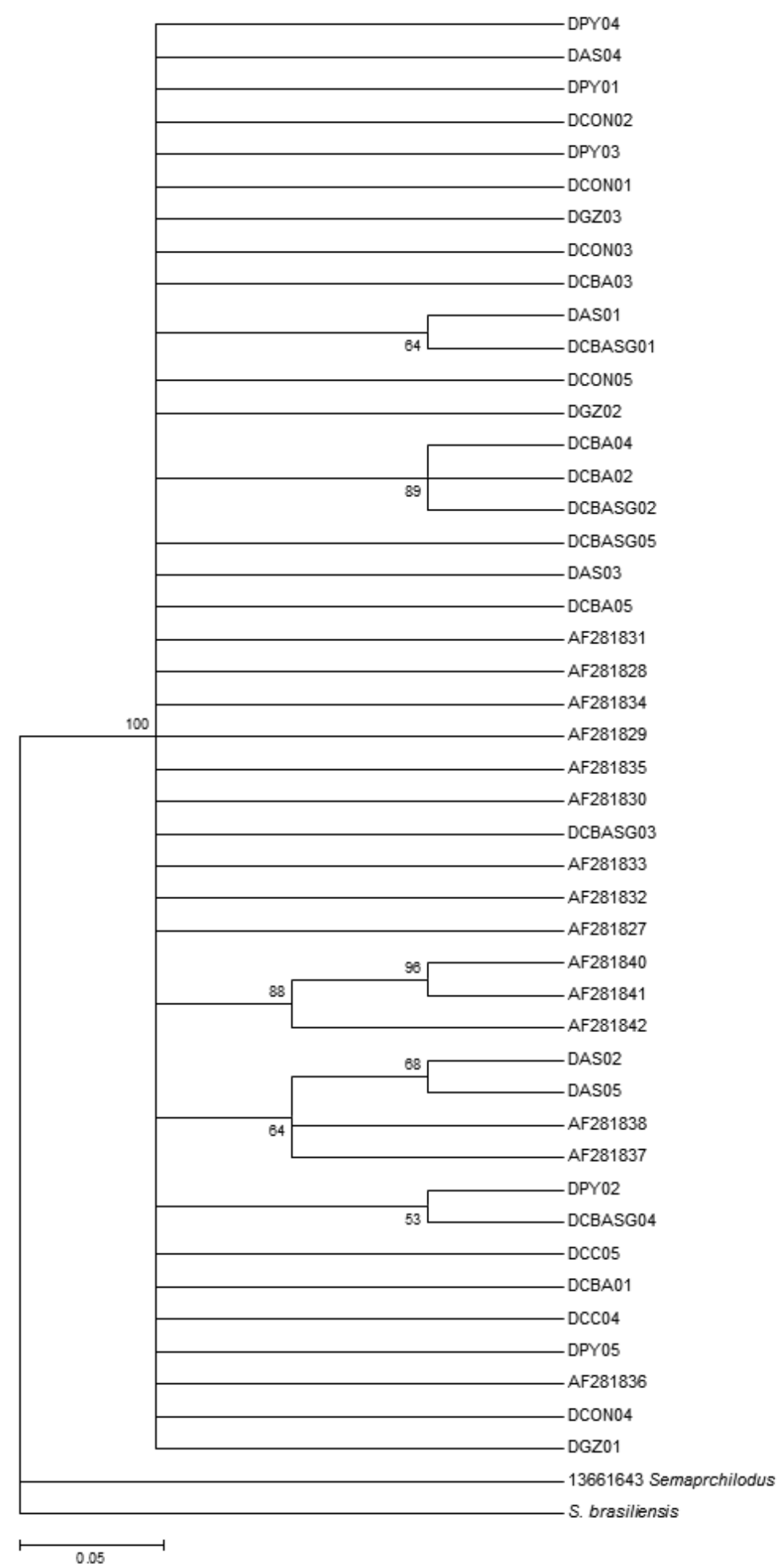

Figue1: b) (supplementary file): Original phylogenetic tree based on the ATPase 6/8 mitochondrial gene using NJ methods. Values on branches present bootstrap values for BI.

The genetic distance calculated within that group presented a relatively low value $(0,5 \%)$, even among populations of different basins (Amazon, Paraguay and Parana basins). We detected high support for this lineage based on bootstrap value $(>80 \%)$. The FST value calculated among Prochilodus lineatus populations were also low $(0,00592)$.

We identified 30 haplotypes divided into two groups with representatives of the Brazilian Paraguay and Paraná Rivers and the Argentine Paraguay River, Uruguay, and Amazon rivers. Among these, 
Phylogeography and population structure of Prochilodus lineatus Valenciennes, 1837 (Pisces: Prochilodontidae) population from the Paraguay River Basin

only six haplo types were shared between the populations from Paraguai/Cuiabá, Paraguai/Cuiabá/Paraná, and Bermejo/Paraguai/Paraná rivers (Figure 2).

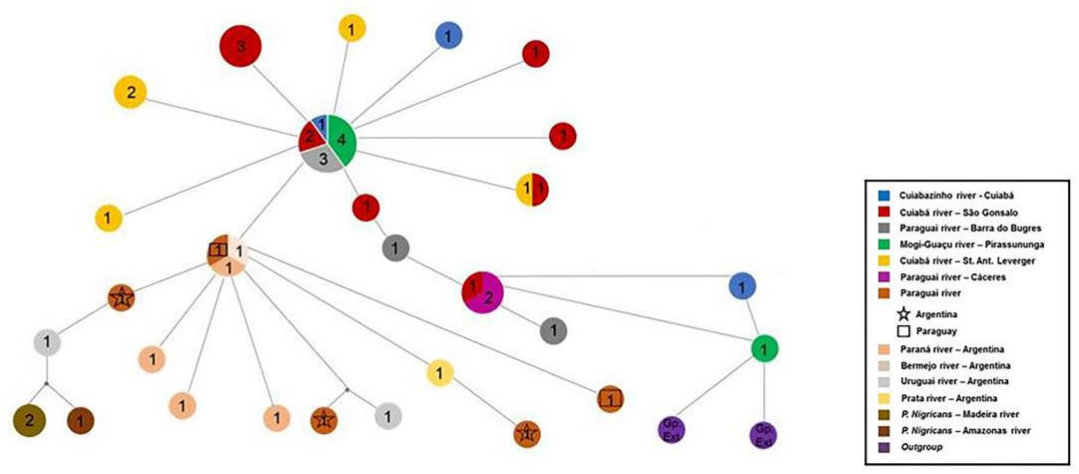

Figure2: Network of haplotypes generated by the Network program

\section{DISCUSSION}

The analyzed population of Prochilodus lineatus had low sequence variation and low AMOVA FST values $(0,00592)$. The low genetic variability in the studied populations may reflect the migratory characteristics of the species; the timing of their migratory behavior corresponds with their reproductive period [17]. Another factor that could explain these genetic characteristics is the flood pulse in the Paraguay River region [18, 19]. This event influences biodiversity in the region [20] (Calheiros \& Ferreira 1997) and was already shown to influence the genetic structure of fish species such as Piabucus melanostomus (Holmberg, 1891) [21].

Other studies indicated that $P$. lineatus has a panmictic population structure [22] based on the low genetic distance and low FST values. These observations suggest that the analyzed population is not genetically structured and have no reproductive or migration barriers. Our results reinforce the hypothesis of a panmictic structure in population of $P$. lineatus in this region.

Based on the two haplotype groups, it is possible to infer the migration route of $P$. lineatus population. The route consistent with the data begins in the upper Paraguay River, moving to the middle and lower portions of the river. Later, there was colonization of the Parana basin (upper Parana: Mogi), the Uruguay River from the lower Parana and Paraguay Rivers.

\section{CONCLUSION}

Our results show the influence of migratory behavior on the genetic structure of population of $P$. lineatus. These biological characteristics resulted in a low genetic distance among individuals from different populations. Our study also reinforces the utility of genetic markers to reveal the demographic history of species of freshwater fish and may help in future conservation plans and management of fishery resources.

\section{ACKNOWLEDGMENTS}

The authors are grateful to Bioedit ${ }^{\circledR}$ by helping with the English language and Fundação de Amparo à Pesquisa do Estado de São Paulo (FAPESP) for financial support.

\section{REFERENCES}

[1] Castro, R.M.C. and R.P. Vari, (2004). Astyanax biotae, a new species of stream fish from the Rio Parapanema basin, upper Rio Paraná system, southeastern Brazil (Ostariophysi: Characiformes: Characidae). Proceedings of the Biological Society of Washington, 117 (3), 330-338.

[2] Mago-Leccia, F. (1972). Consideraciones sobre la sistemática de la familia Prochilodontidae (Osteichthyes, Cypriniformes), con una sinopsis de las especies de Venezuela. Acta Biológica Venezuelica, 8 (1), 35-96.

[3] Jesus, C.M. and Moreira-Filho, O. (2003) Chromosomal location of 5S and 18S rRNA genes in Prochilodus lineatus (Characiformes, Prochilodontidae). Caryologia, 56, 281-287. 
Phylogeography and population structure of Prochilodus lineatus Valenciennes, 1837 (Pisces: Prochilodontidae) population from the Paraguay River Basin

[4] Godoy, M.P. (1975). Peixes do Brasil: Subordem Charachoidei, Bacia do Rio Mogi Guaçu. Piracicaba: Franciscana, 2, 847.

[5] Lessi, E. (1968). Aspectos químicos - bromatológicos de Curimbatá - Prochilodus scrofa: estudo da fração protéica. Revista da Faculdade de Odontologia de Araraquara, 2 (1), 121-132.

[6] Castagnolli, N. and Cyrino, J.E.P... (1980). Desova induzida do Curimbatá Cultura, 32(9), 1215-1253.

[7] Maiardes-Pinto, C.S.R., Paiva, P., Antoniutti, D.M., Verani, J.R., Justo, C.L. (1984). Influência do arraçoamento no crescimento do curimbatá Prochilodus scrofa, em tanques experimentais de cultivo. Anais do III Simpósio Brasileiro de Aqüicultura, pp 313-327.

[8] Aho, T.; Rönn, J.; Piironen, J.; Björklund, M. 2006. Impacts of effective population size on genetic diversity in hatchery reared Brown trout (Salmo trutta L.) populations. Aquaculture, 253: 244-248.

[9] Metzger, J.P. and Casatti, L. 2006. Do diagnóstico à conservação da bio diversidade: o estado da arte do programa BIOTA/FAPESP. Biota Neotropica. 6 (2).

[10] Sambrook, J. and Russell, D.W. (2001). Molecular Cloning: A Laboratory Manual. 3 ed. New York: Cold Spring Harbor Laboratory Press, pp 2344.

[11] Perdices, A., Bermingham, E., Montilla, A., Doadrio, I. (2002). Evolutionary history of the genus Rhamdia (Teleostei: Pimelodidae) in Central America. Molecular Phylogenetics and Evolution, 25, 172-189.

[12] Hall, T.A. (1999). BioEdit: a user-friendly biological sequence alignment editor and analysis program for Windows 95/98/NT. Nucleic Acids, 41, 95-98.

[13] Kimura, M (1980). A simple method for estimating evolutionary rates of base substitutions through comparative studies of nucleotide sequences. Journal of Molecular Evolution, 16 (2), 111-120.

[14] Tamura, K., Peterson, D., Peterson, N., Stecher, G., NEI, M., Kumar, S. (2011). MEGA5: molecular evolutionary genetics analysis using maximum likelihood, evolutionary distance, and maximum parsimony methods. Molecular Biology and Evolution, 28, 2731-2739.

[15] Xia X and Xie Z. DAMBE: Data analysis in molecular biology and evolution. J. Hered. 2001; 92, $371-373$.

[16] Excoffier, L., LAVAL G., Schneider, S. (2005). Arlequin. Version 3.0: an integrated software package for population genetics data analysis. Evolution Bioinformatics, 1, 47-50.

[17] Capeleti, A.R. and Petrere, J.R.M... (2006). Migration of the curimbatá Prochilodus lineatus (Valenciennes, 1836) (Pisces, Prochilodontidae) at the waterfall "Cachoeira de Emas" of the Mogi-Guaçu river - São Paulo, Brazil. Brazilian Journal of Biology, 66 (2), 651-659.

[18] Silva, J.S.V. and Abdon, M.M. (1998). Delimitação do Pantanal Brasileiro e suas subregiões. Pesquisa Agropecuária Brasileira, 33, 1703-1711.

[19] Silva, R.C., Alvalá, R.C.S., Manzil, A.O. \& Souza, A. (2002). Estimativa da radiação de onda longa atmosférica no Pantanal Sul- Matogrossense Durante o período seco de 1999. In XII Congresso Brasileiro de Meteorologia. Foz de Iguaçu.

[20] Calheiros, D.F. and Ferreira, C.J.A. (1997). Alterações limnológicas no Rio Paraguai "dequada" e o fenômeno natural de mortandade de peixes no Pantanal MatoGrossense - MS. Embrapa-CPAP, Corumbá, EMBRAPA-CPAP. Boletim de Pesquisa, 7, 48.

[21] Borba, R.S., Silva, E.L., Ponzetto, J.M., Pozzobon, A.P.B., Centofante, L., Alves, A.L., Parise-Maltempi, P.P. (2013). Population structure of the ornamental tetra Piabucus melanostomus Holmberg, 1891 (Characidae, Iguanodectinae) in the Brazilian Pantanal wetlands inferred by mitochondrial DNA sequences. Biota Neotropica, 13, 42-46.

[22] Sivasundar, A., Bermingham, E., ORTÍ, G. (2001). Population structure and biogeography of migratory freshwater fishes (Prochilodus: Characiformes) in major South American rivers. Molecular Ecology, 10, 407-417.

Citation: R. S. Borba, J. M. Ponzetto, et al., " Phylogeography and population structure of Prochilodus lineatus Valenciennes, 1837 (Pisces: Prochilodontidae) population from the Paraguay River Basin", International Journal of Innovative Studies in Aquatic Biology and Fisheries, vol. 4, no. 1, p. 1-6, 2018. http://dx.doi.org/10.20431/2454-7670.0401001

Copyright: () 2018 Authors. This is an open-access article distributed under the terms of the Creative Commons Attribution License, which permits unrestricted use, distribution, and reproduction in any medium, provided the original author and source are credited. 